\title{
Influence of Some Rhizobium Strains on Chickpea: Nodulation, dry matter yield and Nitrogen uptake
}

\author{
ARM Solaiman $^{1 *}$ MS. Talukder ${ }^{1}$ and MG Rabbani ${ }^{2}$ \\ ${ }^{1}$ Department of Soil Science, Bangabandhu Sheikh Mujibur Rahman Agricultural University, Gazipur 1706. ${ }^{2}$ Grameen Shakti, Grameen Bank Bhaban, Mirpur- \\ 2, Dhaka 1216.
}

(Received 21 August 2010; Accepted 4 December 2011)

\begin{abstract}
Four strains of Rhizobium were isolated from chickpea (Cicer arietinum) to characterize and observe the effectiveness on host legumes. In a laboratory study, Rhizobium strains showed standard pattern of reactions in respect of growth rate, colony characteristics and acid/alkali production on different growth media. The effect of Rhizobium inoculation on nodulation, growth and nitrogen fixation of chickpea was assessed by pot experiment on clay loam soil. Inoculation treatments comprised of Rhizobium strains $\mathrm{CR}_{1}, \mathrm{CR}_{2}, \mathrm{CR}_{3}$ and $\mathrm{CR}_{4}$. Rhizobium inoculation had significant positive effects on nodulation, growth and nitrogen fixation of the crop. Among the Rhizobium strains $\mathbf{C R}_{2}$ and $\mathrm{CR}_{3}$ performed better than $\mathrm{CR}_{1}$ and $\mathrm{CR}_{4}$ at $50 \%$ flowering stage of the crop. There were high positive correlations among the number and dry weight of nodules, $\mathrm{N}$ content and $\mathrm{N}$ uptake by shoot of chickpea.
\end{abstract}

Keywords : Rhizobium, Nodulation, Growth, Nitrogen fixation, Chickpea

Chickpea (Cicer arietinum L.), commonly known as gram, is one of the major pulse crops grown in Bangladesh. It stands $4^{\text {th }}$ in respect of area (13,095 ha) and production (9,630 metric tons) ${ }^{1}$. Nutritionally, chickpea is relatively free from various antinutritional factors, has a high protein digestibility and is richer in phosphorus and calcium than other pulses ${ }^{2}$. Because of its higher fat content and better fiber digestibility, chickpea holds great promise as a protein and calorie source for animal feed for both ruminants and nonruminants ${ }^{3}$. Rhizobium inoculants significantly improves yield in many leguminous crops and can minimize the use of synthetic nitrogenous fertilizer, which is rather expensive and deteriorates soil properties ${ }^{4}$. The crops thus improve soil and economize crop production not only for themselves but also for the next cereals or non-legume crop grown in the rotation and thereby reducing the requirement of added nitrogen fertilizers. Research report showed that Rhizobium inoculation of pea plants added $80 \mathrm{~kg}$ N/ha over uninoculated control $^{5}$. Biological nitrogen fixation and seed yield of soybean significantly increased due to inoculation with Rhizobium ${ }^{6}$. Field trials conducted in Bangladesh showed that grain yield of chickpea increased by 37 to 119\% with Rhizobium inoculation. The number and mass of nodules of chickpea also increased with rhizobial inoculation ${ }^{7}$.

A good number of varieties of chickpea have been developed in Bangladesh over the past years. Some of these varieties are being cultivated by the farmers of Bangladesh but their response to Rhizobium inoculation in respect to nodulation, dry matter production and nitrogen fixation has not been tested. Biological nitrogen fixation technology may be an important tool to increase production of pulses especially chickpea. Keeping these facts in mind the present investigation was, therefore, carried out to characterize some Rhizobium strains isolated from the root nodules of chickpea and to assess their effectiveness in respect of nodulation, dry matter production and nitrogen fixation in host legume.

A laboratory experiment was conducted to characterize four Rhizobium strains isolated from nodules of chickpea collected from Faridpur and Rajbari (AEZ 12). Plants of chickpea were selected randomly from farmers' field of the respected AEZs. Nodules separated from roots of chickpea were washed in fresh water and preserved in vials containing silica gel. The collected nodules were surface sterilized. The nodules were then crushed and streaked on Yeast Extract Mannitol (YEM) agar medium. The strains were assessed for colony characteristics, growth rate and acid/alkali production in laboratory media with a view to know their basic properties prior to intensive study on their performance in respect of nodulation, growth, nitrogen fixation of chickpea. YEM containing the following constituents: $\mathrm{K}_{2} \mathrm{HPO}_{4}$ (0.5g), $\mathrm{MgSO}_{4} .7 \mathrm{H}_{2} \mathrm{O}$ (0.2g), $\mathrm{NaCl}$ (0.1g), $\mathrm{CaCO}_{3}$ (3.0g), $\mathrm{FeCl}_{3} \cdot 6 \mathrm{H}_{2} \mathrm{O}(0.01 \mathrm{~g})$, Mannitol (10.g), yeast extract (0.5g), agar (Difco) (10g), Congo red (02.5\% solution) (10ml), deionized water to 1 litre was used. The initial $\mathrm{pH}$ of the medium was 7.3 which was adjusted to 7.0 by adding $0.1 \mathrm{~N} \mathrm{HCl}$ solution. The medium was inoculated with the Rhizobium strains and incubated

*Corresponding author:

ARM Solaiman, Department of Soil Science, Bangabandhu Sheikh Mujibur Rahman Agricultural University, Gazipur 1706, (Phone) +88-02-9205324

Fax: +88-02-9205333, (E-mail) arm_solaiman@yahoo.com 
for one week. Colonies on plates were observed for their morphology and appearance. The YEM agar medium containing bromothymol blue indicator ${ }^{8}$ was used for identification of strains. The reaction of the rhizobial strains on this medium was noted every week up to four weeks. Fast-growing rhizobial strains produce acid in this medium, turning the medium yellow and slow growing rhizobia produce alkali which turns the medium blue $^{8}$.

A pot experiment was conducted at the Bangabandhu Sheikh Mujibur Rahman Agricultural University to study the effect of Rhizobium isolates on nodulation, growth and nitrogen fixation of chickpea. The soil used in this experiment was sampled from Salna series under Madhupur tract (AEZ 28). The collected soil samples were air-dried, crushed and passed through a sieve. The soil was then autoclaved at $121^{\circ} \mathrm{C}$ for $3 \mathrm{~h}$ to destroy the indigenous organisms inhabiting there in. The soil was clay loam in texture and contained $0.61 \%$ organic carbon, $0.05 \%$ total nitrogen, $0.07 \%$ available P, 0.84 (meq/100g dry soil) exchangeable K, 13.75 (meq/100g dry soil) CEC and had a pH 7.1. Chickpea seeds were collected from Bangladesh Agricultural Research Institute, Joydebpur, Gazipur. The seeds were healthy, vigorous, well matured and free from diseases.

The experiment was laid out in a randomized complete block design (RCRD) with four replications. The treatments were arranged in the experimental units randomly. Inoculation treatments were uninoculated control $\mathrm{CR}_{0}$, Rhizobium strain $\mathrm{CR}_{1}$, Rhizobium strain $\mathrm{CR}_{2}$, Rhizobium strain $\mathrm{CR}_{3}$ and Rhizobium strain $\mathrm{CR}_{4}$. Each pot was filled with $1 \mathrm{~kg}$ of soil. Basal doses of phosphorus (P), potassium (K), zypsum (S), molybdenum (Mo) at the rate of $50 \mathrm{~kg} \mathrm{P}_{2} \mathrm{O}_{5} \mathrm{ha}^{-1}$ (in the form of TSP); $50 \mathrm{~kg} \mathrm{~K}_{2} \mathrm{O} \mathrm{ha}^{-}$ ${ }^{1}$ (in the form of MOP); $20 \mathrm{~kg} \mathrm{Sha}^{-1}$ (in the form of Zypsum) and $1.5 \mathrm{~kg} \mathrm{Mo} \mathrm{ha}^{-1}$ (in the form of Sodium molybdate) were applied to the pots during final pot preparation. No nitrogen fertilizer was used in the experiment. Five germinated seeds were sown in each pot. Liquid inoculants prepared with Rhizobium strains CR1, CR2, CR3 and CR4 having $1.1 \times 10^{8}, 3.5 \times 10^{8}, 2.6 \times 10^{8}$ and $4.3 \times 10^{8}$ viable cells $/ \mathrm{ml}$ were spread on the germinated seeds and were sown in soil.

Two healthy plants per pot were retained after the formation of first trifoliate leaf. All the intercultural operations viz weeding, irrigation and drainage, mulching etc were performed as and when necessary. Plant samples were collected from the pot at 50\% flowering stage (45 days after sowing) of the crop. Plants were carefully uprooted with the help of khurpi so that no nodules were left in the soil. The roots were washed thoroughly with water. The nodules from the roots of each plant were separately collected and counted. The shoot, root and nodule materials were first airdried and then oven- dried at $65^{\circ} \mathrm{C}$ for $72 \mathrm{~h}$. Oven-dried weights of shoot, root and nodule were recorded. The oven-dried plant shoot material was ground in a grinding machine (Wiley Pulverizer, Type 1029-8, Yoshida Seisakusho Co. Ltd). Total N content in the shoot material was determined by ashing the plant material using salicylic acid modified Kjeldahl method following sulfuric acid digestion and then colorimetric assay ${ }^{9}$. The data on various characters of the crop were statistically analyzed to find out the significance of variation resulting from the experimental treatments. For this purpose, analysis of variance was worked out for each character of the crop. The difference between treatment means was compared by Duncan's Multiple Range Test.

Colonies of rhizobial strains absorbed very little of the congo red dye. Results presented in Table 1 show that Rhizobium strain $\mathrm{CR}_{2}$ absorbed the dye very weakly, strains $\mathrm{CR}_{1}, \mathrm{CR}_{3}$ and $\mathrm{CR}_{4}$ exhibited weak absorption of the dye. This result is consistent with that of Trinick ${ }^{10}$ who reported that rhizobia absorbed the dye weekly compared with other bacteria. Growth on peptone glucose agar as reported by Vincent ${ }^{11}$ indicates that most of the Rhizobium strains grow either poorly or moderately in this medium. Strain $\mathrm{CR}_{1}$ showed poor growth on the medium. Strains $\mathrm{CR}_{2}, \mathrm{CR}_{3}$ and $\mathrm{CR}_{4}$ showed moderate growth on the medium. Colony characteristics showed that strain $\mathrm{CR}_{1}$ was found to be slow-growing on YEM agar. This strain produced large confluent colonies with abundant gum in YEM agar after 5 to 7 days of incubation. In contrast the strains $\mathrm{CR}_{2}, \mathrm{CR}_{3}$ and $\mathrm{CR}_{4}$ showed fast growth in this medium (Table 1). Colonies of these strains on YEM agar appeared small and separate with slight gum production. The texture of the gum was usually sticky. The importance of production of acid or alkali by the various rhizobia has been emphasized when considering Rhizobium taxonomy ${ }^{8}$. In this study all fast growing Rhizobium strains showed acidic reactions throughout their four weeks of growth, while slowgrowing Rhizobium strains started with an alkaline reaction after one week of growth (Table 1). It was observed that the strains $\mathrm{CR}_{2}, \mathrm{CR}_{3}$ and $\mathrm{CR}_{4}$ produced acidic reaction on this medium. These strains turned green color of the medium to yellow. Strain $\mathrm{CR}_{1}$ produced alkali on this medium, which turned green color of the medium to blue. Rhizobium strains showed visible turbidity in YEM broth after 5 to 7 days of incubation. All the strains produced moderate turbidity in this medium after ten days. The differences in texture of extra cellular polysaccharide of the fastand slow-growing rhizobia have been shown to be due to differences in monosaccharide comparison ${ }^{12}$.

The effect of Rhizobium inoculation on number of nodules per plant of chickpea was significant (Table 2). The highest number of effective nodule was obtained with the strain $\mathrm{CR}_{3}$, which was statistically similar to the strain CR2. The lowest number of effective nodule was obtained with the strain $\mathrm{CR}_{4}$ (Table 2). These results are in agreement with the findings of Alam et $a l^{13}$ who conducted a pot experiment and found that Rhizobium inoculation significantly increased number of nodule in chickpea. These results also support the findings of Solaiman ${ }^{14}$ who reported that Rhizobium inoculation significantly increased number of nodule per plant in mungbean. The highest number of total nodule was obtained with the strain $\mathrm{CR}_{3}$. The second highest number of total nodule was obtained with the strain $\mathrm{CR}_{2}$. Solaiman and Rabbani ${ }^{15}$ 
Table 1: Characteristics of some Rhizobium strains isolated from root nodules of chickpea

\begin{tabular}{|c|c|c|c|c|c|}
\hline $\begin{array}{l}\text { Rhizobium } \\
\text { strains }\end{array}$ & $\begin{array}{l}\text { Growth on } \\
\text { congo red } \\
\text { YEM agar } \\
\text { (Absorption } \\
\text { of dye) }\end{array}$ & $\begin{array}{c}\text { Growth on } \\
\text { peptone } \\
\text { glucose } \\
\text { agar }\end{array}$ & $\begin{array}{c}\text { Colony } \\
\text { characteristics } \\
\text { on YEM agar } \\
\text { (Fast/slow) }\end{array}$ & $\begin{array}{l}\text { Acid/alkali } \\
\text { production in } \\
\text { YEM agar } \\
\text { medium } \\
\text { containing } \\
\text { BTB } \\
\end{array}$ & $\begin{array}{l}\text { Growth in } \\
\text { YEM broth }\end{array}$ \\
\hline CR3 & Weak & Moderate & Fast & Acid & Moderate turbidity \\
\hline CR4 & Weak & Moderate & Fast & Acid & Moderate turbidity \\
\hline
\end{tabular}

observed that pea inoculated with Rhizobium inoculants produced the highest number of nodules at pre-flowering and pod filling stages. The highest dry weight of effective nodules was obtained with the strain $\mathrm{CR}_{2}$ which was statistically similar to the strain $\mathrm{CR}_{3}$ (Table 2). This result are in agreement with Solaiman et al. ${ }^{16}$ who conducted experiment on chickpea and found significantly higher dry weight of nodule due to Rhizobium inoculation. Eusuf Zai et al. ${ }^{17}$ conducted a pot experiment on chickpea and found that Rhizobium inoculation increased dry weight of nodules. Plants inoculated with the strain $\mathrm{CR}_{3}$ produced the highest dry weight of total nodule. Strain $\mathrm{CR}_{2}$ produced the second highest dry weight of total nodules. The lowest dry weight of total nodules was obtained with strain $\mathrm{CR}_{4}$. There was a positive correlation between the number and dry weight of nodules. The highest plant height was recorded by the strain $\mathrm{CR}_{3}$ which was statistically similar to the strains $\mathrm{CR}_{2}$ and $\mathrm{CR}_{1}$ (Table 3). The lowest plant height was obtained with uninoculated control, which was statistically similar to $\mathrm{CR}_{4}$. This result is similar to the findings of Alam et al. ${ }^{13}$ who obtained higher plant height due to inoculation over uninoculated control. The highest root length was obtained with the strain $\mathrm{CR}_{2}$, which was statistically similar to the strains $\mathrm{CR}_{1}$ and $\mathrm{CR}_{3}$ (Table 3 ). The lowest root length was obtained with the control, which was statistically similar to the strain $\mathrm{CR}_{4}$. Maura et al. ${ }^{18}$ stated that inoculation of chickpea seed increased root growth of the plant. The highest dry weight of shoot was recorded by $\mathrm{CR}_{2}$, which was statistically similar to strain $\mathrm{CR}_{1}$ (Table 3). The lowest dry weight of shoot was recorded with uninoculated control, which was statistically similar to the strains $\mathrm{CR}_{4}$ and $\mathrm{CR}_{3}$. This result supports the findings of Solaiman et al. ${ }^{16}$, who found significantly higher plant height and dry weight of shoot over control due to inoculation in chickpea. There was a positive correlation $(\mathrm{r}=0.628)$ between the dry weight of effective nodules and dry weight of shoot of chickpea. It is evident from Table 3 that dry weight of root was influenced due to Rhizobium inoculation. Plant inoculated with the strain $\mathrm{CR}_{3}$ produced the highest dry weight of root, which was $77 \%$ higher than control. The second highest dry weight of root was recorded from the strain $\mathrm{CR}_{2}$ followed by $\mathrm{CR}_{4}$. The lowest dry weight of root was obtained with the control. The highest amount of $\mathrm{N}$ content in shoot was obtained with the strain $\mathrm{CR}_{3}$ which was statistically similar to the strains $\mathrm{CR}_{1}$ and $\mathrm{CR}_{2}$ (Table 4). The lowest $\mathrm{N}$ content in shoot was obtained with the uninoculated control. Nitrogen content in shoot had a positive correlation with the number and dry weight of nodules. The highest $\mathrm{N}$ uptake was recorded by the strain $\mathrm{CR}_{1}$ which was statistically similar to the strain $\mathrm{CR}_{2}$ (Table 4). The lowest $\mathrm{N}$ uptake by shoot was recorded from control. All the strains performed better than uninoculated control considering $\mathrm{N}$ uptake by shoot. Khan et al. ${ }^{19}$ found that single application of Rhizobium inoculant significantly increased nitrogen uptake by shoot compared to control. A positive relationship ( $\mathrm{r}=0.764$ ) between dry weight of effective nodules and $\mathrm{N}$ uptake by shoot in chickpea was observed.

Table 2: Effect of Rhizobium inoculation on number and dry weight of nodules of chickpea

\begin{tabular}{|c|c|c|c|c|}
\hline \multirow[t]{2}{*}{ Inoculation treatment } & \multicolumn{2}{|c|}{ Number of nodules/plant } & \multicolumn{2}{|c|}{ Dry weight of nodules/plant (mg) } \\
\hline & Effective & Total & Effective & Total \\
\hline Control(Uninoculated) & $0.00 \mathrm{~d}$ & $0.00 \mathrm{e}$ & $0.00 \mathrm{~d}$ & $0.00 \mathrm{e}$ \\
\hline $\mathrm{CR}_{2}$ & $19.50 \mathrm{a}$ & $33.50 \mathrm{~b}$ & 9.33 a & $10.96 \mathrm{~b}$ \\
\hline $\mathrm{CR}_{3}$ & $21.00 \mathrm{a}$ & $41.00 \mathrm{a}$ & $9.32 \mathrm{a}$ & $12.25 \mathrm{a}$ \\
\hline CV (\%) & 9.33 & 10.35 & 8.96 & 13.27 \\
\hline
\end{tabular}

Means in a column followed by same letter(s) are not significantly different at 5\% level of DMRT 
Table 3: Effect of Rhizobium inoculation on plant height, root length, dry weight of shoot and root of chickpea

\begin{tabular}{|c|c|c|c|c|}
\hline $\begin{array}{l}\text { Inoculation } \\
\text { treatment }\end{array}$ & $\begin{array}{l}\text { Plant } \\
\text { height } \\
(\mathrm{cm})\end{array}$ & $\begin{array}{c}\text { Root } \\
\text { length } \\
(\mathrm{cm})\end{array}$ & $\begin{array}{c}\text { Dry } \\
\text { weight of } \\
\text { shoot (mg) }\end{array}$ & $\begin{array}{c}\text { Dry } \\
\text { weight of } \\
\text { root (mg) }\end{array}$ \\
\hline $\begin{array}{l}\text { Control } \\
\text { (Uninoculated) }\end{array}$ & 19.25 c & $16.50 \mathrm{~b}$ & $1465.00 \mathrm{~b}$ & $440.00 \mathrm{c}$ \\
\hline CR1 & $23.25 \mathrm{ab}$ & $20.25 \mathrm{a}$ & $1887.00 \mathrm{a}$ & $502.50 \mathrm{c}$ \\
\hline CR2 & $25.25 \mathrm{a}$ & $21.50 \mathrm{a}$ & $1992.00 \mathrm{a}$ & $620.00 \mathrm{~b}$ \\
\hline CR3 & $26.25 \mathrm{a}$ & $19.75 \mathrm{a}$ & $1527.00 \mathrm{~b}$ & $777.50 \mathrm{a}$ \\
\hline CR4 & 21.25 bc & $16.25 \mathrm{~b}$ & $1540.00 \mathrm{~b}$ & 502.50 bc \\
\hline CV (\%) & 11.25 & 15.65 & 17.63 & 13.65 \\
\hline
\end{tabular}

Means in a column followed by same letter(s) are not significantly different at $5 \%$ level by DMRT

Table 4: Effect of Rhizobium inoculation on $N$ content in shoot and $N$ uptake by shoot of chickpea

\begin{tabular}{lcc}
\hline Inoculation treatment & $\begin{array}{c}\text { N content } \\
\text { in shoot (\%) }\end{array}$ & $\begin{array}{c}\text { N uptake by shoot } \\
\text { (mg/plant) }\end{array}$ \\
\hline Control (Uninoculated) & $1.71 \mathrm{c}$ & $26.21 \mathrm{c}$ \\
$\mathrm{CR}_{1}$ & $3.16 \mathrm{ab}$ & $64.72 \mathrm{a}$ \\
$\mathrm{CR}_{2}$ & $3.12 \mathrm{ab}$ & $57.34 \mathrm{a}$ \\
$\mathrm{CR}_{3}$ & $3.25 \mathrm{a}$ & $45.53 \mathrm{~b}$ \\
$\mathrm{CR}$ & $2.84 \mathrm{~b}$ & $43.53 \mathrm{~b}$ \\
$\mathrm{CV}(\%)$ & 8.26 & 12.22 \\
\hline
\end{tabular}

Means in a column followed by same letter(s) are not significantly different at $5 \%$ level of DMRT.

\section{References}

1. BBS. 2007. Year Book of Agricultural Statistics of Bangladesh. Bangladesh Bureau of Statistics, Ministry of planning. Govt. of the Peoples Republic of Bangladesh, Dhaka. p. 62.

2. ICRISAT. 1990. Chickpea in the Nineties: Proc. Sec. Inter Workshop on Chickpea Improvement. International Crops Research Institute for the Semi-Arid Tropics, ICRISAT Asia Centre, India.

3. Ramalho - Ribero, JMC and Portugal - Melo IM. 1988. Composition and nutritive value of chickpea. In: Proc. Conference on Present Status and Future Prospects of Chickpea Crop Production and Improvement in the Meditennaean Countries, 11-13 July 1988. Zanagoza, Spain. J.I. Cubero; M.C. Saxena and J. Wery (eds.). Zaragoza, Spain: Centre International de Hautes Etudes Agronomiques Mediaterraneennes.

4. Cordesse R. 1988. Value of chickpea as animal feed. In: Proc. Conference on Present Status and Future Prospects of Chickpea Crop Production and
Improvement in the Mediterranean Countries, 11-13 July 1988, Zaragoza, Spain. J.I. Cubero; M.C. Saxena and J. Wery (eds.). Zaragoza, Spain: Centre International de Hautes Etudes Agronomiques Mediterraneenes.

5. Micanovic D, Saric Z, Raicevic V, Jevtic S and Lazic. 1997. Possibility of nitrogen fixation in Pisum sativum and Triticum aestivum. Proc. of the first Balkan Symposium on Vegetables and Potatoes. Acta Hort. 2(462): 823-827.

6. Solaiman ARM. 1999. Effects of Bradyrizobium japonicum inoculation and molybdenum on soyabean. Bangladesh J. Bot. 28(2): 42-46.

7. Khanam D, Rahman MHH, Hossain AKM, Anwar MN and Rahman AFM. 1994. Effect of Rhizobium inoculation and varietal interaction on yield of chickpea at Gangetic Flood Plain. Bangladesh J Microbiol. 11 (2): $67-71$.

8. Norris DO. 1965. Acid producation of Rhizobium. A unifying concept. Plant Soil. 22. 143-166.

9. Cataldo DA, Schrader IE and Young VI. 1974. Analysis by digestion and colorimetric assay of total nitrogen in plant tissues high in nitrate. Crop Sci. 14: 854-856.

10. Trinick MJ. 1982. Biology. In: Nitrogen Fixation Volume 2: Rhizobium (WJ Broughton Ed) pp. 76-146. Clarendon Press, Oxford.

11. Vincent JM. 1970. A manual for the practical study of root nodule bacteria. Blackwell Scientific Publication, Oxford.

12. Bailey RW, Greenwood RM and Craig A. 1971. Extracellular polysaccharides of Rhizobium strains associated with Lotus species. $J$ Gen Microbiol. 65: 315-324.

13. Alam MJ, Solaiman ARM, Karim AJMS and Hossain MT. 1999. Potential of some Rizobium strains on nodulation, nitrogen fixation, crop growth and dry matter production of chickpea. Bangladesh J. Microbiol. 16(2): 107-114.

14. Solaiman ARM. 1999. Respose of mungbean to Bradyrizobium sp. (Vigna) inoculation with and without phosphorus and potassium fertilization. Bangladesh J Sci Res. 17(2): 125-132.

15. Solaiman ARM and Rabbani MG. 2003. Performance of pea as affected by Rhizobium inoculant, N, P, K and Mo application. Bangladesh J Soil Sci. 27(2): 13-22.

16. Solaiman ARM, Khan MSH and Hoque MS. 1999. Effects of Rizobium inoculant and NPK on nodulation, growth and yield of chickpea (Cicer areitinum L.). J Asiat Soc Bangladesh Sci. 25(2): 181-188.

17. Eusuf Zai AK, Solaiman ARM and Ahmed JU. 1999. Response of some chickpea varieties to Rizobium inoculation in respect of nodulation, biological nitrogen fixation and dry matter yield. Bangladesh J Microbiol. 16(2): 135-144.

18. Maurya BR, Sanoria CL and Ram PC 1987. Combined culture treatment enhanced nodulation, yield and quality of chickpea. Seeds and Farms. 13(8): 25-33.

19. Khan MSH, Solaiman ARM, Hoque MS and Rahman MM. 1997. Response of chickpea to Rizobium inoculation and NPK fertilization on nodulation, dry matter production and $\mathrm{N}$ uptake. Ann Bangladesh Agric. 7(1): 21-26. 